\title{
Theofilos
}

A Nordic open access journal in Theology, Philosophy and Culture

Published by NLA University College - in partnership with Johannelund School of Theology

Available at www.theofilos.no

\section{Freedoms and Limitations: C. S. Lewis and Francis Schaeffer as a tag team ${ }^{1}$}

\author{
C. John Collins \\ Professor of Old Testament \\ Covenant Theological Seminary, St. Louis, Missouri \\ Jack.Collins@covenantseminary.edu
}

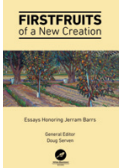

We are grateful for the permission to re-publish this tribute by Genesis specialist C. John ("Jack") Collins to his colleague and friend Jerram Barrs. A version of this article was first published in Firstfruits of a New Creation: Essays Honoring Jerram Barrs (2019).

Barrs was a Worker at L'Abri Fellowship in UK for many years before joining the Faculty at Covenant Theological Seminary in 1989. He was instrumental in founding The Francis Schaeffer Institute as a "means of extending and embodying the legacy of Dr. Francis A. Schaeffer within the context of seminary education". ${ }^{2}$

Some of the ideas from C. S. Lewis in this article are further developed by Jack Collins in Reading Genesis Well: Navigating History, Poetry, Science, \& Truth in Genesis 1-11 (Zondervan, 2018).

The Editors

I count it a great delight to contribute this essay in honor (or should I say, in honour?) of Professor Jerram Barrs, especially since he (together with his associate Ranald Macaulay), Francis Schaeffer, and C. S. Lewis have done so much to shape my own thinking and living as a Christian. To have Professor Barrs as a colleague, and a friend, is a privilege beyond my wildest imagining. And if I focus on Genesis 1-11 in this essay, consider that a tribute to my sharing the 2010 Francis A. Schaeffer lectureship with Professor Barrs on that topic. ${ }^{3}$

\section{Francis Schaeffer introduces "freedoms and limitations"}

Francis Schaeffer (1912-84) had a major influence on Jerram Barrs. Schaeffer served as a Bible Presbyterian pastor in St Louis, and then as a missionary in Europe; he founded and operated L'Abri, with its orientation toward young people. As a pastor and apologist within the great Christian tradition, Schaeffer was convinced that there was "no final conflict" between the sciences and the Bible, when both are properly understood.

But many do interpret the sciences and the Bible as being in conflict; and these alleged conflicts can be the most acute when it comes to the story of origins: the origin of the universe, of life, of the varieties of life forms, and especially of humankind. Christians have tried various ways to address these conflicts; Schaeffer, being both an evangelist eager to remove barriers to coming to Christian faith, and 
a theologian knowing that we must preserve the true Christian faith without diluting it, aimed to give some guidance on just how to address those potential barriers. Schaeffer was also a churchman, considering unnecessary conflict within the church to be destructive of Christian wellbeing and witness.

For these reasons Schaeffer articulated an approach to origins that he called "freedoms and limitations": there is a range of reasonable scenarios by which we may address the apparent conflicts between the Bible and the sciences, and yet there are limits to this range, limits set both by basic Biblical concepts and by good human judgment. 4

Schaeffer was willing to consider, among other freedoms, the possibility that Genesis 1 describes God creating a "grown up universe" (nowadays called the "appearance of age hypothesis"); or that God was reforming a creation that had been partially deformed by Satan's fall; or that the "days" refer to long ages. He concluded, sensibly and generously:

I urge you again to remember that I am not saying that any of these positions are my own or that they will prove to be the case. I am simply stating theoretical possibilities as we consider the correlations between what the Bible sets forth about cosmogony and what we can study from general revelation.

At the same time he wanted to insist, first, on God's special creative activity at certain places; in particular, at the original creation, and then at the creation of conscious life, and again at the creation of man, the result was discontinuous in some way from what had preceded. He also thought it essential to say that Adam was the first man and that Eve was made from him. This left him with a careful view of what is called "theistic evolution": he saw no support for the molecule-to-man sort of naturalistic evolution, and he imagined that anyone who held to his limitations would not be an evolutionist in the fullest sense of the word.

When it comes to assessing Schaeffer's version of specific freedoms and limitations, the first thing to do is to recognize that he has covered the main options that evangelicals in his day had explored. And surely his instincts are right: these explorations come from obviously good people, who are competent scholars; why should we get worked up over their differences? At the same time, a great deal of water has gushed on by under the exegetical bridge since his booklet first saw publication in 1975, and thus I would take his list of freedoms as enumerative and suggestive, rather than exhaustive. The limitations strike me as eminently reasonable, and indeed generous - and, as we will see, they fit well with the arguments of C. S. Lewis.

Further, Schaeffer's approach allows what we might call a "glass half full" style of ministry, whose main goal is to help people adequately face the facts about their humanness - we are distinct from the other animals, and we all need God - without quibbling over every detail. This approach allows us to affirm people, and leave them to develop their own perspectives further - traits that I have seen vividly embodied in Jerram Barrs!

So, all these factors certainly make me admire Schaeffer. In addition, I think another factor, unstated, comes into play as well: namely, a sane Christian has a hierarchy of commitments, and thus, for example, should insist more strongly on the tenets of "mere" or "basic" Christianity - say, the Trinity, or the resurrection of Jesus - than on some other matters 
that are important, but not quite so vital - say, the number of sacraments and their exact effects. Since I am, like Schaeffer and Barrs, a Presbyterian, I appreciate as well the ideal of "generic Calvinism," which allows a range of possible views on a number of matters, within the circle of the Reformed ministry. ${ }^{5}$

My admiration for Schaeffer's approach grows even greater when I add into the mix some insights from C. S. Lewis, the literary scholar. In my judgment, Lewis' insights show that the very nature of the material we have in Genesis leads to some sort of freedoms and limitations rubric, since the material both resists a purely literalistic reading, and invites a recognition of its historical impulse.

In this essay I want to develop these insights from Lewis, and in places to refine them (since they touch on my own area of specialization, namely Genesis). I will also draw on Lewis to defend this approach against some of its critiques, which are still current. And if at times I think I can improve on some particulars in their outlooks, I still think that a "broadly Lewisian" and "broadly Schaefferian" tack when it comes to Genesis will provide us with the intellectually and morally robust tools we need for bringing the message of Genesis to each culture. ${ }^{6}$

\section{What kind of introduction does}

\section{S. Lewis need?}

C. S. Lewis (1898-1963), famous both as a defender of Christian faith and as the writer of imaginative fiction, actually had a day job: he was a professional scholar of medieval and Renaissance European literature. From 1925 until 1954, he was Fellow and Tutor in English Literature at Magdalen College, Oxford; and from 1954 until he retired in 1963 (shortly before he died that same year), he was Professor of
Medieval and Renaissance Literature at Cambridge University. In the course of his academic work he produced books and papers on topics in ideological history, English philology, and literary interpretation, many of which still show considerable value.

Nowadays the general public knows Lewis primarily for the theological, apologetic, and imaginative works; nevertheless his total work hangs together, and the same personal traits come through in all of his writings.

Lewis the apologist wrote when the standard narrative in the Western world was that the advances of the sciences were relegating the archaic beliefs of traditional religions such as Christianity to the museum. As he put it, ${ }^{7}$

It is a common reproach against Christianity that its dogmas are unchanging, while human knowledge is in continual growth. Hence, to unbelievers, we seem to be always engaged in the hopeless task of trying to force the new knowledge into moulds which it has outgrown. I think this feeling alienates the outsider much more than any particular discrepancies between this or that doctrine and this or that scientific theory. ... For him it seems clear that, if our ancestors had known what we know about the universe, Christianity would never have existed at all.

As Christians sought to adapt to the new knowledge, many skeptics held these efforts in contempt; as Lewis put it: ${ }^{8}$

My friend Corineus has advanced the charge that none of us are in fact Christians at all. According to him historic Christianity is something so barbarous that no modern man can really believe it: the moderns who claim to do so are in fact believing a modern system of 
thought which retains the vocabulary of Christianity and exploits the emotions inherited from it while quietly dropping its essential doctrines.

Lewis took it to be his job to defend the essentials of Christian belief, and to show that these essentials wear well as they encounter modern trends of thought.

Lewis portrayed himself as a purveyor of traditional Christianity; but he made his own contributions as well. For example, it has been common in Christian thinking to treat the Bible as a virtually disjointed collection of stories, poems, doctrinal treatises, ethical discourses and so forth. Since about 1990, Christian students of Biblical theology have become more explicitly aware of the over-arching story of the Bible, and of the powerful role that story plays in forming the worldview of a community. As Albert Wolters and Michael Goheen put it, ${ }^{9}$

To miss the grand narrative of Scripture is a serious matter; it is not simply a matter of misinterpreting parts of Scripture. It is matter of being oblivious to which story is shaping our lives. Some story will shape our lives. When the Bible is broken up into little bits and chunks - theological, devotional, spiritual, moral, or worldview bits and chunks - then these bits can be nicely fitted into the reigning story of our own culture with all its idols! One can be theologically orthodox, devotionally pious, morally upright, or maybe even have one's worldview categories straight, and yet be shaped by the idolatrous Western story. The Bible loses its forceful and formative power by being absorbed into a more encompassing secular story.

One way of marking key episodes in this unfolding story is the rubric, "Creation, Fall, Redemption, and Consummation.”10
Lewis was, at least with respect to mainstream Biblical theology, ahead of the game in his attention to the narrative unity of the Christian message. ${ }^{11}$ As early as 1947, in his book Miracles, he was describing world history (which its redemptive component) as "this great story ... a very long story, with a complicated plot."12 In his 1950 essay, "Historicism," he was even more explicit: ${ }^{13}$

For Christianity, ... history is a story with a well-defined plot, pivoted on Creation, Fall, Redemption, and Judgement.

And again, in his Cambridge lectures introducing the medieval picture of the world, published posthumously in 1964 as The Discarded Image, he wrote: 14

History, in a word, was not for them [the Greeks] a story with a plot. The Hebrews, on the other hand, saw their whole past as a revelation of the purposes of Yahweh. Christianity, going on from there, makes world-history in its entirety a single, transcendentally significant, story with a well-defined plot pivoted on Creation, Fall, Redemption, and Judgement.

Many theologians are coming to recognize that their doctrinal formulations must do justice to this narrative structure, and I will return to this theme. For now I simply want to notice that a literary scholar, with no special training in Biblical studies or theology, had seen something that is now acknowledged as old hat. Perhaps his further observations, as I will discuss below, will be likewise fruitful. ${ }^{15}$

\section{Lewis discusses textual features of Genesis}

In his Reflections on the Psalms, Lewis made it clear that he was not what he called a "Fundamentalist"; he did not define the term, but it appears from the context that 
he meant someone with "a prior belief that every sentence of the Old Testament has historical or scientific truth." 16 And Lewis added,

But this [prior belief] I do not hold, any more than St. Jerome did when he said that Moses described Creation "after the manner of a popular poet" (as we should say, mythically) or than Calvin did when he doubted whether the story of Job were history or fiction.

(By the way, this version of "fundamentalism" is often assumed to be entailed by another principle that Schaeffer held to, namely the "inerrancy" of the Bible. No doubt this frequent assumption is due to the fact that plenty of "inerrantists" exist who do indeed fall into that kind of "fundamentalism."17 But the overall principle does not require it. Interestingly enough, Lewis himself touches on some of the linguistic, literary, and philosophical matters that, combined with disciplines such as speech act theory and rhetoric, can provide the tools for articulating a sound notion of Biblical truthfulness - but I shall have to develop that elsewhere. ${ }^{18}$ )

Lewis here refers to Jerome, but no one has located the exact spot in which Jerome makes this claim. The closest source is a passage in the English protoReformer John Colet (1467-1519), who wrote in a letter to one Radulphus: 19

Thus Moses arranges his details in such a way as to give the people a clearer notion, and he does this after the manner of a popular poet, in order that he may the more adapt himself to the spirit of simple rusticity, picturing a succession of things, works, and times, of such a kind as there certainly could not be in the work of so great a Workman.

With this principle in mind, Lewis addresses the possibility that the creation story in Genesis is in some way "derived from earlier Semitic stories which were Pagan and mythical" - a view that had become widely spread by his time, and which was held to discredit Genesis. But Lewis shows his good literary and philosophical sense by first insisting, "We must of course be quite clear what 'derived from' means. Stories do not reproduce their species like mice." He observed that it is persons who do the retelling, and revising of stories, for various ends:

Thus at every step in what is called - a little misleadingly - the "evolution" of a story, a man, all he is and all his attitudes, are involved. And no good work is done anywhere without aid from the Father of Lights. When a series of such re-tellings turns a creation story which at first had almost no religious or metaphysical significance into a story which achieves the idea of true Creation and of a transcendent Creator (as Genesis does), then nothing will make me believe that some of the re-tellers, or some one of them, has not been guided by God.

Hence, although Lewis found much that he deemed poetical, or even mythical, in the Genesis creation story, he was nevertheless willing to attach to it some kind of referent. For example:

We read in Genesis $(2,7)$ that God formed man of the dust and breathed life into him. For all the first writer knew of it, this passage might merely illustrate the survival, even in a truly creational story, of the Pagan inability to conceive true Creation, the savage, pictorial tendency to imagine God making things "out of" something as the potter or the carpenter does. Nevertheless, whether by lucky accident or (as I think) by God's guidance, it embodies a profound principle. For 
in any view man is in one sense made "out of" something else. He is an animal; but an animal called to be, or raised to be, or (if you like) doomed to be, something more than an animal. On the ordinary biological view (what difficulties I have about evolution are not religious) one of the primates is changed so that he becomes man; but he remains still a primate and an animal.

(For some examples of Lewis' delight in seeing humans as a special kind of animal, see below.)

Now, Lewis elsewhere makes it clear that he thought this "changing" of one of the primates to become man was both historical and supernatural. ${ }^{20}$ Thus the poetical or pictorial style of the Genesis story does not prevent it from referring to a real event in the history of the world.

Several ways of qualifying and refining Lewis' observations here immediately come to mind; and as I consider them, I hope that we do not lose sight of the "broadly Lewisian" character of the revision that results.

The first refinement addresses Lewis' interpretation of the phrase in Jerome or Colet, "after the manner of a popular poet" as "mythically," or as "in the form of a folk tale" (in the parallel passage in Miracles). ${ }^{21}$ A chief difficulty in appreciating what Lewis meant here comes from the multiple definitions of the English word "myth," together with the fact that Lewis himself did not consider that word a derogatory categorization. From Lewis' own discussion it appears that he does not intend to suggest that the tale has no historical referentiality; but he is clear that we do not discern whatever referentiality it has by way of a literalistic reading.

For the reader not attuned to all of Lewis' intended nuances, it would be bet- ter to turn to the context of the passage in Colet, the only known source for Lewis' description. Colet's phrases "give the people a clearer notion" and "simple rusticity" point the way; and earlier in the same place, Colet indicates that Moses' object "was not to give to the learned of future generations a scientific statement of the manner and order of the creation of the universe, but to teach a moral lesson to the people whom he was leading out of the bondage and idolatry of Egypt." That is, Colet is not contrasting the literary type of myth or folk tale with a literary type of "history," but rather the popular account with the scientific. The popular account does not even pretend to give the kind of details that the learned scholars seek, about the exact order of events, or the inner workings of the things described. It is content with vivid, pictorial description, and trusts the reader or hearer with the responsibility of using the account properly, namely with allowing the story to capture the imagination and loyalty of the community that owns it.

A further refinement speaks to Lewis' acknowledgement that other ancient Near Eastern origin stories are relevant to the meaning of Genesis. Much has happened in the study of the ancient Near East since Lewis' time. While it was once common to suppose that the Babylonian poem Enuma Elish was the relevant "ancestor" of the Genesis creation story,22 and though some Biblical scholars still think this way, Assyriologists now find in Genesis 1-11 a set of "parallels" to some much older Mesopotamian sources. ${ }^{23}$ To call them "parallels" highlights the problems connected with "derivation"; it allows that Genesis is a response to, a comment upon, or even a refutation of, the Mesopotamian stories, without saying what 
the exact literary relationship is (or even whether specific texts were in mind).

And what do these parallels tell us about the function of Genesis 1-11? The Mesopotamian sources provide what Assyriologist William Hallo calls "prehistory" - the story of the period of human existence before there are any secure written records - and "protohistory" - tales of the earliest stages for which there are records. ${ }^{24}$ Another way to put this is to recognize that these materials provide what we can call the front end of the official Mesopotamian worldview story. Further, it appears that the Mesopotamians aimed to accomplish their purpose by founding their stories on what they thought were actual events, albeit told with a great deal of imagery and symbolism. Thus it is reasonable to take Genesis 1-11 as having a similar purpose in Israel, expecting similar attention to history without undue literalism: these stories explain to ancient Israel where they came from, how things got be the way they are, and why God has called Israel to exist in the first place (to restore the whole of God's world to a condition of "blessing"). 25

Lewis rightly, therefore, recognized the hermeneutical caution that good readers should exercise when approaching Genesis 1-11. His own scholarly studies had made him vividly aware of the problem. In discussing a medieval writer who takes older poetical works too literalistically he says, ${ }^{26}$

The poet is ranked with the scientist as authority for a purely scientific proposition. This astonishing failure or refusal to distinguish - in practice, though not always in theory - between books of different sorts must be borne in mind whenever we are trying to gauge the total effect of an ancient text on its medieval readers.

Lewis speaks further of "the medieval failure to distinguish between writers of wholly different kinds," and gives as an example, "A highly lyrical passage from Job (xxxix. 19-25) is here being turned into a proposition in natural history." 27

A further example of a failure along the lines that Lewis exposes is the effort to describe the "Biblical" picture of the world, as a flat place, possibly disc-shaped, with mountains at the extremities supporting the sky, which is a solid dome with an actual body of water above it; below the land we find an ocean and the subterranean pillars of the earth. Unlike the medievals that Lewis was writing about, scholars' purpose for this description is not to adopt it, but to warrant rejecting the Biblical picture for its primitivity. Such a description appears in, for example, the United Bible Societies' Handbook on Genesis, which makes its appeal to passages such as Psalm 104:2-3, 5-9; 148:4; Job 26:11; 37:18; 38:4-11; Proverbs 8:28-29; Amos 9:6.28 In view of the general sensitivity to linguistic, literary, and rhetorical matters in the UBS series, it is surprising to realize that the list of texts is entirely of poetical passages, with no assessment of the different kinds of texts and what one might have to do to ascertain their presupposed picture of the world. ${ }^{29}$ I wonder what Lewis would say about this way of reading!

Further, Lewis the historian of literature helps us to appreciate that one of the literary techniques at work in Genesis may well be what we call "anachronism," portraying past events in light of the author's and audience's present world. This was certainly a feature of medieval European literature; as Lewis noted, the 
medievals "pictured the whole past in terms of their own age. So did the Elizabethans. ... It is doubtful whether the sense of period is much older than the Waverley novels." 30 This need not detract from the "historicity" of the text, since the text can still refer to actual events without making any kind of strong claim about the details of the characters' circumstances. An example in Genesis would be the term "city" for the very early kind of settlement in Genesis 4:17.

Some may prefer a higher level of literalism in their reading of Genesis than Lewis did, and that preference is legitimately open to discussion. Nevertheless the broadly Lewisian points still stand: first, the possible effect of "pagan" stories on the origin of Genesis need not detract from its inspiration; and second, the possibility (in my mind, the near assurance) of shared motifs and literary conventions with other ancient near Eastern stories need not detract from the referentiality, nor even from the historicity, of the Genesis material - so long as we do not identify historicity with literalism in interpretation. 31

\section{An example: The origin and fall of human beings}

The flow of this essay is headed toward the conclusion that the presence of pictorial material and literary conventions in Genesis 1-11 shows that an approach like Schaeffer's is surely the best way for believers to hold and commend their faith in the larger world.

C. S. Lewis fits into this pattern. For example, he was happy to entertain a variety of scientific-historical scenarios for the origin of humankind, but none of them would be valid if they were to deny the mystery of reason, or any implications that follow from that mystery.
Likewise, these scenarios must not deny the objectivity of ethical judgments.

Consider, for example, his treatment of human origins in the context of his chapter on "The Fall of Man" in The Problem of Pain. ${ }^{32}$ In discussing the Biblical story of Adam and his sin, and the degree to which that event may have affected the rest of us (traditionally the descendants of Adam and Eve), he acknowledges this about "the Fathers" (the leading theologians in the first few Christian centuries):

$$
\begin{aligned}
& \text { Wisely, or foolishly, they believed } \\
& \text { that we were really - and not simp- } \\
& \text { ly by legal fiction - involved in } \\
& \text { Adam's action. }
\end{aligned}
$$

Now, Lewis wanted to do justice to this belief, at the same time as he recognized that 20th century scientific beliefs ran contrary to a literalistic reading. So he set about addressing, with his characteristic clarity, how these two sets of beliefs might relate to one another. "Many people think that this proposition" - that God created Man good, but then Man fell by disobedience - "has been proved false by modern science," with its view that "men have arisen from brutality and savagery."

There seems to me to be a complete confusion here. Brute and savage both belong to that unfortunate class of words which are sometimes used rhetorically, as terms of reproach, and sometimes scientifically, as terms of description; and the pseudo-scientific argument against the Fall depends on a confusion between the usages. If by saying that man rose from brutality you mean simply that man is physically descended from animals, I have no objection. But it does not follow that the further back you go the more brutal - in the sense of wicked or wretched - you will find man to be. 
Lewis insisted, "Science, then, has nothing to say either for or against the doctrine of the Fall," and proceeded to offer a scenario that he thought might be "a not unlikely tale":

For long centuries, God perfected the animal form which was to become the vehicle of humanity and the image of Himself. He gave it hands whose thumb could be applied to each of the fingers, and jaws and teeth and throat capable of articulation, and a brain sufficiently complex to execute all of the material motions whereby rational thought is incarnated. ... Then, in the fullness of time, God caused to descend upon this organism, both on its psychology and physiology, a new kind of consciousness which could say "I" and "me", which could look upon itself as an object, which knew God, which could make judgments of truth, beauty and goodness, and which was so far above time that it could perceive time flowing past. ... We do not know how many of these creatures God made, nor how long they continued in the Paradisal state. But sooner or later they fell. Someone or something whispered that they could become as gods. ... They wanted some corner in the universe of which they could say to God, "This is our business, not yours." But there is no such corner. They wanted to be nouns, but they were, and eternally must be, mere adjectives. We have no idea in what particular act, or series of acts, the selfcontradictory, impossible wish found expression. For all I can see, it might have concerned the literal eating of a fruit, but the question is of no consequence.

It is clear from the context, and from Lewis' other writing, that by "God caused to descend upon this organism, both on its psychology and physiology, a new kind of consciousness" he meant something that was supernatural; as he said in Miracles, "To believe that Nature produced God, or even the human mind, is, as we have seen, absurd." 33 And notice that this "new kind of consciousness" enables the creature to reason about transcendent moral realities, which again cannot be a simple outgrowth of its material capacities.

We might want to revise this scenario in some of its particulars; I have offered my own revisions for it elsewhere, and my result is still "broadly Lewisian." 34 The point here is that, according to Lewis, whatever the details of the story we tell about human origins, there are limits to what we may suggest and still be within the bounds of good critical thinking - which, as Lewis would insist, is necessary if we want to be practicing good science.

What applies to the origin of humankind applies to evolutionary theory in general. Lewis mentioned evolution frequently in his writings, generally to distinguish the scientific theory from the ideological extrapolations some made of it (which he ranked as a "Myth"). But he said a few things about the theory itself. A fair sample would be this: ${ }^{35}$

Again, for the scientist Evolution is a purely biological theorem. It takes over organic life on this planet as a going concern and tries to explain certain changes within that field. It makes no cosmic statements, no metaphysical statements, no eschatological statements. ... It does not in itself explain the origin of organic life, nor of the variations, nor does it discuss the origin and validity of reason. It may well tell you how the brain, through which reason now operates, arose, but that is a different matter. Still less does it even attempt to tell you 
how the universe as a whole arose, or what it is, or whither it is tending. But the Myth knows none of these reticences. ... 'Evolution' (as the Myth understands it) is the formula of all existence.

The kind of evolutionary theory that did not bother Lewis theologically "does not in itself explain the origin of organic life, nor of the variations, nor ... of reason"; that is, it does not insist beforehand that we may only allow a purely naturalistic scenario for the whole development of life (though he has not ruled that out). ${ }^{36}$

Nominally, at least, some leading evolutionary biologists support Lewis on this. For example, D. M. S. Watson (1886-1973), Professor of Zoology and Comparative Anatomy at University College, London (1921-1951), acknowledged: "But whilst the fact of evolution is accepted by every biologist the mode in which it has occurred and the mechanism by which it has been brought about are still disputable." 37 The National Science Teachers Association (NSTA) says something very similar:

There is no longer a debate among scientists about whether evolution has taken place. There is considerable debate about how evolution has taken place: What are the processes and mechanisms producing change, and what has happened specifically during the history of the universe?

Even though these statements sensibly refuse to decide ahead of time what kinds of factors can be involved, other statements are emphatic in ruling some things out. The National Association of Biology Teachers (NABT) insists: ${ }^{38}$

Evolutionary biology rests on the same scientific methodologies the rest of science uses, appealing only to natural events and processes to describe and explain phenomena in the natural world. Science teachers must reject calls to account for the diversity of life or describe the mechanisms of evolution by invoking non-naturalistic or supernatural notions.

(I do not suggest here that Lewis thought that "non-naturalistic" notions must be involved in any extensive fashion, nor whether any of these would be readily perceptible to human students, nor even whether it was appropriate for him to have much of an opinion - except, of course, in the origin of humankind.)

It is therefore reasonable, in light of what kind of text Genesis 1-11 is, first, to refuse to dictate to the paleontologist what he or she may find in the fossils, or a geneticist in the genome. At the same time, when that geneticist or paleontologist wants to try to put those findings together into larger theories that tell the human story, then that person is reasoning as a human being, and his or her reasoning must comply with good reasoning. As Lewis wrote in another context, 39

Now I dread specialists in power because they are specialists speaking outside their special subjects. Let scientists tell us about sciences. But government involves questions about the good for man and justice, and what things are worth having at what price; and on these a scientific training gives a man's opinion no added value.

A white lab coat does not confer a privileged status to one's dicta in every subject!

Consider some more of the features that Lewis touches on, which distinguish humans from the rest of the animals. The motivation for science itself is distinctively human: "One of the things that distinguishes man from the other animals is 
that he wants to know things, wants to find out what reality is like, simply for the sake of knowing." 40 Human friendship is another feature that resists explanation purely in terms of natural development of animal capacities: ${ }^{41}$

Friendship is - in a sense not at all derogatory to it - the least natural of loves; the least instinctive, organic, biological, gregarious and necessary. ... We can live and breed without Friendship. The species, biologically considered, has no need of it. ...

[Friendship] has no survival value; rather it is one of those things which give value to survival.

Some researchers have indeed tried to argue that human friendship is continuous with some aspects of animal behavior, but they must rest their argument on defining friendship down. A 2003 survey article in Science News, entitled "Beast buddies," concludes: "Harder to understand though, according to Silk, are the bonds so close and widespread in Homo sapiens. She says, 'None of our models of reciprocity [among nonhuman animals] can accommodate the psychology of human friendship." 42

Humans even carry out their romantic loves in a way that shows both their animality and their distinctiveness: 43

For I can hardly help regarding it as one of God's jokes that a passion so soaring, so apparently transcendent, as Eros, should thus be linked in incongruous symbiosis with a bodily appetite which, like any other appetite, tactlessly reveals its connections with such mundane factors as weather, health, diet, circulation, and digestion. ... It is a continual demonstration of the truth that we are composite creatures, rational animals, akin on one side to the angels, on the other to tom- cats. It is a bad thing not to be able to take a joke.

The other animals are uniformly serious!

Lewis would have us believe that there is something fundamentally unreasonable in the insistence (such as the NABT has apparently made) that even humankind arose by a purely natural process; and since it is unreasonable, it is bad scientific history. And Lewis had undoubtedly met people who made just such an insistence, even in the name of "science." Of them he said, ${ }^{4}$

They ask me at the same moment to accept a conclusion and to discredit the only testimony on which the conclusion can be based. The difficulty is to me a fatal one; and the fact that when you put it to many scientists, far from having an answer, they seem not even to understand what the difficulty is, assures me that I have not found a mare's nest but detected a radical disease in their whole mode of thought from the very beginning.

To see how Lewis' approach helps us to face contemporary challenges, consider this example. Anthony Cashmore is a professor of biology at the University of Pennsylvania, specializing in "the mechanism by which plants respond to light." 45 He was elected to the National Academy of Sciences in 2003, and the Proceedings of the National Academy of Sciences published his inaugural article, "The Lucretian swerve: The biological basis of human behavior and the criminal justice system," in 2010.46 Cashmore aims to show that, since human behavior is the product of genes, environment, and "stochastic" factors (that is, they are probabilistic), therefore there is no such thing as free will. This in turn means that "individuals cannot logically be held respon- 
sible for their behavior"; which then leads to Cashmore's purpose for writing, namely a proposal to reform the American criminal justice system.

In making the argument about how the biological factors determine behavior, Cashmore does cite a few studies in cognitive science, regarding the relationship between measurable brain activity and human choices. He does not claim that anyone actually understands the brain processes, or what consciousness is; he rather expects that at some point we will have a full explanation for how it arises from the chemical properties of the nervous system. He nevertheless insists, "as living systems we are nothing more than a bag of chemicals"; "not only do we have no more free will than a fly or a bacterium, in actuality we have no more free will than a bowl of sugar. The laws of nature are uniform throughout, and these laws do not accommodate the concept of free will."

Because "progress in understanding the chemical basis of behavior will make it increasingly untenable to retain a belief in the concept of free will," therefore "it is time for the legal system to confront this reality." All of the reforms he proposes stem from "the elimination of the illogical concept that individuals are in control of their behavior in a manner that is something other than a reflection of their genetic makeup and their environmental history," and this will "hopefully minimize the retributive aspect of criminal law." Persons convicted of crimes will then be given the appropriate psychiatric help (as specified by a "court-appointed panel of experts").

There is much to say about the overall logic of Cashmore's argument, and many of the details as well. For now I will content myself with observing that Lewis would surely point out that Cashmore, in declaring our thoughts to be merely a biological phenomenon, has undercut anyone's right to believe such a claim. Cashmore seems to have taken it as fundamental to science that we must seek purely material and, apparently, reductionistic, explanations for everything.

Lewis, who wrote, “A man's rational thinking is just so much of his share in eternal Reason as the state of his brain allows to become operative," 47 would not be surprised at the close connection between brain activity and decisions, although he would likely also point out how little these findings actually do explain. He would surely also note what problems we make for ourselves if we suppose that it is even reasonable to posit that chemical events in the brain, strictly speaking, cause thoughts or choices.

Further, we recognize that free will and moral responsibility are parts of a larger realm of discourse, in which there is some transcendent norm that we are obligated to comply with. And Cashmore has not evaded such transcendence. Why does he not suggest that we simply eliminate those who commit crimes - whether from the population, or at least from the gene pool (say, by sterilization)? Surely it is because he sees as clearly as anyone else that we should not do such horrors to our fellow humans. Why does he think we ought to restructure our criminal justice system? Is it not because he considers it unjust to punish people for things for which they are not responsible? And who gets to choose these panels of experts, what kind of decision-making does he expect from them, and to whom will they be accountable? Will they be "wrong" if they accept bribes or other favors? I must believe that Cashmore expects everyone to behave with the utmost honesty and 
fairness, and that they are blameworthy if they do not. And even to make the case for something, to try to persuade us that it is true, is in effect to insist that the readers ought to believe it, and are culpable if they do not. 48

It is to Cashmore's credit that he commits these inconsistencies: they are his humanity breaking through. As Lewis put it, "Holding a philosophy which excludes humanity, they yet remain human.... They know far better than they think they know." 49 We might suspect that Lewis would add, along with his Professor Digory Kirke, “Logic! Why don't they teach logic at these schools?" 50

\section{Objection: These "adjustments" take leave of the Biblical presentation}

I have already cited a passage from Lewis where he imagined his friend Corineus objecting to a project such as I have discussed here, namely that we are no longer talking about the Biblical world (see $\$ 2$ above).

Indeed, in words that oddly echo Corineus, the Biblical scholar Peter Enns has made exactly this objection to my own study on Adam and Eve: 51

Collins's synthesis requires an ad hoc hybrid "Adam" who was "first man" in the sense of being either a specially chosen hominid or a larger tribe of early hominids (Collins is careful not to commit himself to either option). ... Further, this type of hybrid "Adam," clearly driven by the need to account for an evolutionary model, is not the Adam of the biblical authors.

For now I leave aside the question of whether Enns has presented and analyzed my argument carefully (I think he clearly did not), because I am not aiming to defend the specifics of my own work here, except insofar as I am "broadly Lewi- sian." 52 I will instead focus our attention on his words, not the Adam of the biblical authors, with its echo of Corineus.

How does Lewis help us think through such an objection? First, Lewis has reminded us that the material in Genesis 1-11 contains a good deal of pictorial description: and this means, both that we must be careful of undue literalism, and that the material can still have a referent. Enns seems to be suggesting that only a literalistic reading of the Genesis material is true to the Bible writers on their own terms, and that any effort to relate that to "science" departs from the Bible writers altogether (a departure he advocates). .53

The British New Testament scholar N. T. Wright seems to understand things better than Enns when he discusses the apostle Paul's use of Adam in Romans 5:54

Paul clearly believed that there had been a single first pair, whose male, Adam, had been given a commandment and had broken it. Paul was, we may be sure, aware of what we would call mythical or metaphorical dimensions to the story, but he would not have regarded these as throwing doubt on the existence, and primal sin, of the first historical pair. Our knowledge of early anthropology is sketchy, to put it mildly. Each time another very early skull is dug up the newspapers exclaim over the discovery of the first human beings; we have consigned Adam and Eve entirely to the world of mythology, but we are still looking for their replacements. What "sin" would have looked like in the early dawn of the buman race it is impossible to say; but the turning away from open and obedient relationship with the loving creator, and the turning toward that which, though beautiful and enticing, is not God, is such a many-sided phenomenon that it is 
not hard to envisage it at any stage of anthropoid development. The general popular belief that the early stories of Genesis were straightforwardly disproved by Charles Darwin is of course nonsense, however many times it is reinforced in contemporary myth-making. Things are just not that simple, in biblical theology or science.

Lewis deals with the ideas at the base of this objection: ${ }^{55}$

Remembering, as I do, from within, the attitude of the impatient sceptic, I realize very well how he is forearmed against anything I might say for the rest of this chapter. "I know exactly what this man is going to do," he murmurs. "He is going to start explaining all these mythological statements away ... ." ... I freely admit that "modernist" Christianity has constantly played just the game of which the impatient sceptic accuses it. But I also think there is a kind of explaining which is not explaining away. ... I am going to distinguish what I regard as the "core" or "real meaning" of the doctrines from that in their expression which I regard as inessential and possibly even changed without damage.

Lewis draws a distinction between the "core" of a Christian doctrine and the particular form by which some people might picture the relevant events, and he reminds us, "Christianity is not to be judged from the fancies of children any more than medicine from the ideas of the little girl who believed in horrid red things." ${ }_{56}$

He then asks us to imagine a scenario: 57

We can suppose a Galilean peasant who thought that Christ had literally and physically "sat down at the right hand of the Father." If such a man had then gone to
Alexandria and had a philosophical education he would have discovered that the Father had no right hand and did not sit on a throne... Even if it could be shown, then, that the early Christians accepted their imagery literally, this would not mean that we are justified in relegating their doctrines as a whole to the lumber room. Whether they actually did, is another matter. The difficulty here is that they were not writing as philosophers to satisfy speculative curiosity about the nature of God and of the universe. ... Hence the sort of question we are now considering is never raised by the New Testament writers. When once it is raised, Christianity decides quite clearly that the naif images are false. ... We do not find similar statements in the New Testament, because the issue has not yet been made explicit: but we do find statements which make it certain how that issue will be decided when once it becomes explicit.

Or, as he puts it in another place, 58

The answer is that the alternative we are offering [the early Christians] was probably never present to their minds at all. As soon as it was present, we know quite well which side of the fence they came down on....

The earliest Christians were not so much like a man who mistakes the shell for the kernel as like a man carrying a nut which he hasn't yet cracked. The moment it is cracked, he knows which part to throw away. Till then he holds on to the nut, not because he is a fool but because he isn't.

Besides Alexandrian analysis, what sorts of principles do we have that can guide us, ensuring that we are keeping the kernel? One overlooked factor in Lewis that I have alluded to is the notion of the over- 
arching storyline of the Bible. The story begins with a transcendent God who made a good world, with its human inhabitants morally innocent. By some sort of disobedience they pulled themselves and their offspring astray from God's good plan, and God's activity is thereafter redemptive - that is, he is constantly aiming to provide "forgiveness for having broken, and supernatural help towards keeping, that law," that universal law embedded in the good creation..$^{59}$ The freedoms leave some room for discussion over just what kinds of scenarios we will be intellectually satisfied with; but the shape of the story puts a limit on our speculations: we want to be sure that we are still telling the same story. This, by the way, is why we should not take Lewis' image of the kernel and shell too strictly: that is, the Biblical way of describing things retains its value as the proper way to envision the events and scenery, because that imagery shapes our attitudes. Hence, we are not free to "throw it away" in every sense, and Lewis himself did not.

Corineus' objection, then - as exemp- lified by Peter Enns - stems from a drastic oversimplification, and thus from actual misunderstanding.

\section{Conclusions}

C. S. Lewis, Francis Schaeffer, and Jerram Barrs have shown us how the Biblical story, sometimes summarized as Creation, Fall, Redemption, and Consummation, rings true: it actually accounts for what we find in ourselves and in the world. That story is, in fact, the true Big Story that makes sense of our lives. I admire the passion with which these men have sought to bring the truth of this Big Story to bear on a wide range of human activities - indeed, on all of life.

Such an endeavor will meet difficulties, and our faith obligates us to make our best effort to address these difficulties with full intellectual rigor and honesty. By combining the profound insights of Lewis and Schaeffer into a sensible program of "freedoms and limitations" we have the tools we need for responsible and faithful discussions of our origins.

\footnotetext{
Notes

1 [Eds.] This tribute to Jerram Barrs was originally published in Doug Serven (ed.) Firstfruits of a New Creation. Essays in Honor of Jerram Barrs (Oklahoma City, OK: White Blackbird Books, 2018), pp. 183-208. It is re-published here with the kind permission of both author, editor, and publisher.

2 [Eds.] See https://www.covenantseminary.edu/francis-schaeffer-institute/.

3 [Eds.] Jerram Barrs is Professor of Christian Studies \& Contemporary Culture, Senior Scholar-in-Residence of the Francis Schaeffer Institute, and Francis Schaeffer Chair of Apologetics at Covenant Theological Seminary. See further https://www.covenantseminary.edu/faculty/jerram-barrs/.

4 Francis A. Schaeffer, No Final Conflict (London: Hodder and Stoughton / Downers Grove, IL: Inter Varsity Press, 1975), ch. 3. This appears also in Francis A. Schaeffer, The Complete Works of Francis A. Schaeffer (Westchester, IL: Crossway, 1982), vol. 2.

5 Robert Letham uses this expression in his The Westminster Assembly: Reading its theology in historical context (Phillipsburg, NJ: P \& R, 2009), 3, 176, 182 ("The Assembly was not partisan body within the boundaries of its generic Calvinism, but allowed differing views to coexist.”), 365. Letham drew on Benjamin Warfield, The Westminster Assembly and its Work (New York: Oxford University Press, 1934), 136:

"obviously it was generic Calvinism they were intent on asserting and not any particular variety of it."

6 Although I have long thought along these lines, I attribute the delightful term "broadly Lewisian" to Steven Jon James Lovell, Philosophical Themes from C. S. Lewis (University of Sheffield PhD, 2003), e.g. p. 10.

7 C. S. Lewis, God in the Dock: Essays on theology and ethics (Walter Hooper, ed.; Grand Rapids:

Eerdmans, 1970), 38 ("Dogma and the universe," 1943). Since many of Lewis' works appear in several editions, with different page numbers (and some of these are online), and since the collections of essays gather things written at different times, my convention for citing Lewis is the following: the books I will cite from the edition I own, but also with the chapter or section number; the essays I will cite from the collection, but also with the title and (probable) date.
} 
8 Lewis, God in the Dock, 63 ("Myth became fact," 1944).

9 Albert M. Wolters and Michael W. Goheen, Creation Regained: Biblical Basics for a Reformational Worldview 2nd ed. (Grand Rapids: Eerdmans, 2005), 125.

10 Wolters and Goheen offer the idea of a play in six acts, Creation, then Fall, then Israel, then Jesus in the Gospels, then the post-Easter Church, and then the consummation - thus splitting Redemption up into three parts.

11 One can find various titles such as Abraham Oakes, A short essay on the creation, fall, and redemption of man (London, 1750), and T. R. Birks, The Difficulties Of Belief In Connexion With The Creation And The Fall, Redemption And Judgment (London, 1876). One might further find this narrative structure to underlie the famous "fourfold state of man" of authors such as Thomas Boston; but the influence of this structure on Biblical studies and theology seems (to me at least) small. Readers of the Greek Christian theologian Athanasius (296-373) will recognize that he has structured his two major apologetic works, Against the Heathen and On the Incarnation of the Word of God, around just this storyline.

12 C. S. Lewis, Miracles: A preliminary study (1 ${ }^{\text {st }}$ edition; London: Geoffrey Bles, 1947), 119-20 (ch. 12); (2 ${ }^{\text {nd }}$ edition; New York: Macmillan, 1960), $98-99$ (the edition I usually cite).

13 C. S. Lewis, "Historicism," in Christian Reflections (Walter Hooper, ed.; Grand Rapids: Eerdmans, 1967), $100-113$, at 103 .

14 C. S. Lewis, The Discarded Image: An introduction to Medieval and Renaissance literature (Cambridge: Cambridge University Press, 1964), 174. See also the incidental mention earlier in the book: "the Christian doctrines of man's creation, fall, redemption, and resurrection" (28).

15 For more general reflections on aspects of Lewis' thought, see my essay, "A peculiar clarity: How C. S. Lewis can help us think about faith and science," in John G. West, ed., The Magician's Twin: C. S. Lewis on Science, Scientism, and Society (Seattle: Discovery Institute Press, 2012), 69-106.

16 Lewis, Reflections on the Psalms (London: Geoffrey Bles, 1958), 109 (ch. 11).

17 For a similar difficulty, cf. Lesslie Newbigin, Proper Confidence: Faith, doubt, and certainty in Christian discipleship (Grand Rapids: Eerdmans, 1995), 84-92-a difficulty no doubt due both to Newbigin's contact with "fundamentalists" of this type, and to the general obscurity (or even non-availability) of a more sophisticated approach.

18 I do have such a work in preparation. See further, for example, the essays in D. A. Carson and John D. Woodbridge, eds., Hermeneutics, Authority and Canon (Leicester: Inter-Varsity Press, 1986).

19 From his second letter to Radulphus (1497); English translation from Frederick Seebohm, The Oxford Reformers (London: Longmans, Green, \& Co., 1869), 51 (italics original). Another translation, with the Latin original, appears in J. H. Lupton, ed., Letters to Radulphus on the Mosaic Account of the Creation, Together with Other Treatises, by John Colet, M.A. (London: George Bell, 1876), 9-10. The wording quoted suggests that Lewis had read the Seebohm edition of the letters (Lupton's rendering is "after the manner of some popular poet," which is also close). It is possible that Lewis mistakenly attributed this to Jerome, since he is well-known to have quoted often from memory - see Walter Hooper's "Preface" to Lewis, Selected Literary Essays (Walter Hooper, ed.; Cambridge: Cambridge University Press, 1969), xvii. But it is also possible that Colet did actually derive this view from Jerome, as he did so many other views. In the first letter to Radulphus, Colet had mentioned Jerome as a careful scholar familiar with the original Hebrew. Credit for tracking down this reference goes to the blog post and comments at

alltheblognamesalreadytaken.wordpress.com/2008/05/29/cs-lewis-and-st-jerome/.

20 This point follows from Lewis' argument in his Miracles, regarding the special status of mind, which cannot be explained as merely the material operations of the brain. See also his Problem of Pain (London: Geoffrey Bles, 1940), ch. 5.

21 Lewis, Miracles, 33 (ch. 4); God in the Dock, 42 ("Dogma and the universe," 1943).

22 See the discussion in Alexander Heidel, The Babylonian Genesis (Chicago: University of Chicago Press, 1951) - a book that addresses issues that were current in Lewis' time.

23 For discussion and documentation, see my Did Adam and Eve Really Exist? Who they were and why you should care (Wheaton, IL: Crossway, 2011), Appendix 1.

24 William W. Hallo, "Part 1: Mesopotamia and the Asiatic Near East," in William W. Hallo and William K. Simpson, eds., The Ancient Near East: A history (Fort Worth, TX: Harcourt Brace College Publishers, 1998), $3-181$, at 25 .

25 I make these points more fully in in chapter 2 and Appendix 1 of Did Adam and Eve Really Exist? An example of missing this point comes from Daniel Harlow, "After Adam: Reading Genesis in an age of evolutionary science," Perspectives on Science and Christian Faith 62.3 (2010): 179-95; at 185-87, Harlow notices symbolic and pictorial elements in both Genesis and the Mesopotamian sources, and pronounces them both unhistorical. He is confusing historicity with a literalistic scheme of interpretation, without argument.

26 Lewis, Discarded Image, 31. 
27 Lewis, Discarded Image, 147-48.

28 William D. Reyburn and Euan McG. Fry, Handbook on Genesis (New York: United Bible Societies, 1997), 27.

29 Likewise, in what is actually a good book (which I have commended), Davis Young and Ralph Stearley, The Bible, Rocks and Time (Downers Grove: InterVarsity, 2008), dismiss appeal to phenomenal language as an "attempt to avoid the force of the [Genesis] statement" (207), apparently unaware of all the linguistic, literary, and rhetorical issues they have swept under the rug.

30 Lewis, Discarded Image, 183. "The Waverley novels" refers to a class of historical fiction that began in the early $19^{\text {th }}$ century (as in Sir Walter Scott's Waverley, 1814).

31 For more detail, see my Did Adam and Eve Really Exist, $\$ 2$ b. I also employ a number of Lewisian and Schaefferian ideas in my contributions to Matthew Barrett and Ardel Canaday, eds., Four Views on the Historical Adam (Grand Rapids: Zondervan, 2013) - not only in my chapter, but also in my comments on the other contributions.

32 Lewis, Problem of Pain, ch. 5.

33 Lewis, Miracles, 32 (ch. 5).

34 See my discussion in my Did Adam and Eve Really Exist, $\$ 5$ d; I propose my own "freedoms and limitations" in $\$ 5 \mathrm{c}$. In my discussion of Lewis, I draw attention to his bafflement over the solidarity concept that underlies the Biblical picture. Hence it fascinated me to discover after my book's publication that Lewis continued to wish for greater light on this topic: in a letter written in 1951, more than 10 years after The Problem of Pain, he wishes he had known more about how the notion of "members of one another" works; letter, 12 September 1951, cited in Richard Purtill, C. S. Lewis' Case for the Christian Faith (San Francisco: Ignatius, 2004 [1985]), 56. This idea is part of what New Testament scholars now call "interchange," and it is part of the larger question of corporate solidarity among the people of God. 35 Lewis, Christian Reflections, 86 ("The funeral of a great myth," ca. 1945). Lewis may very well be reflecting a comment by G. K. Chesterton, whom he admired: "No philosopher denies that a mystery still attaches to the two great transitions: the origin of the universe itself and the origin of the principle of life itself. Most philosophers have the enlightenment to add that a third mystery attaches to the origin of man himself. In other words, a third bridge was built across a third abyss of the unthinkable when there came into the world what we call reason and what we call will," in The Everlasting Man (Garden City: Doubleday, 1955 [1925]), 27. A work that Lewis praised, Arthur James Balfour, Theism and Humanism (New York: Hodder \& Stoughton, 1915), makes this point as well. And, interestingly enough in view of Schaeffer's connection to "Old Princeton" Seminary, David Livingstone has shown that Benjamin Warfield wound up with a very similar approach to evolution; see Livingstone, Darwin's Forgotten Defenders (Grand Rapids: Eerdmans, 1987). Hence Lewis' reservations about what natural "evolution" can accomplish resonate with Schaeffer's freedoms and limitations cited at the head of this essay.

36 J. B. S. Haldane, whom Lewis mentioned often, certainly did want to claim that evolutionary biology ruled out any possibility of conventional theistic religion being true. He states this plainly in his essays "Darwinism today," "When I am dead," and "Science and theology as art forms" in Possible Worlds and Other Essays (New Brunswick, NJ: Transaction Publishers, 2002 [1927]); see further Gordon McOuat and Mary P. Winsor, “J. B. S. Haldane's Darwinism in its religious context," British Journal for the History of Science 28.2 (1995): 227-31.

37 Watson, "Adaptation," Report of the Ninety-Seventh Meeting British Association for the Advancement of Science (London: Office of the British Association, 1929), 88-99, at 88.

38 These two statements were accessed in January of 2016: "NSTA Position Statement: The Teaching of Evolution," 2003, http://www.nsta.org/about/positions/evolution.aspx “NABT Position Statement on Teaching Evolution," adopted in 1995 and modified in 1997, 2000, 2004, 2008, and 2011, http://www.nabt.org/websites/institution/?p=92. (Earlier versions held that "natural selection ... has no specific direction or goal," but this has been removed - so at least a teleological reading of the whole process is allowed for.)

39 Lewis, God in the Dock, 315 ("Is progress possible? Willing slaves of the welfare state," 1958).

40 Lewis, God in the Dock, 108 ("Man or rabbit?," 1946).

41 Lewis, The Four Loves (London: Geoffrey Bles, 1960), 70, 84 (ch. 4). In the same chapter Lewis observes, "To those-and they are now the majority - who see human life merely as a development and complication of animal life all forms of behaviour which cannot produce certificates of an animal origin and of survival value are suspect" (71).

42 Susan Milius, “Beast buddies,” Science News 164:18 (November 1, 2003), 282-84.

43 Lewis, The Four Loves, 116 (ch. 5).

44 Lewis, The Weight of Glory and Other Addresses (Walter Hooper, ed.; New York: Simon \& Schuster, 1996 [1980]), 103 ("Is theology poetry," 1944); cf. Christian Reflections, 89 ("Funeral of a great myth," ca. 1945). See also God in the Dock, 135 ("Religion without dogma?," 1946), where Lewis notes that there are different levels of openness to religion in the different scientific disciplines: "It is as their subject matter comes nearer to man himself that their anti-religious bias hardens." 


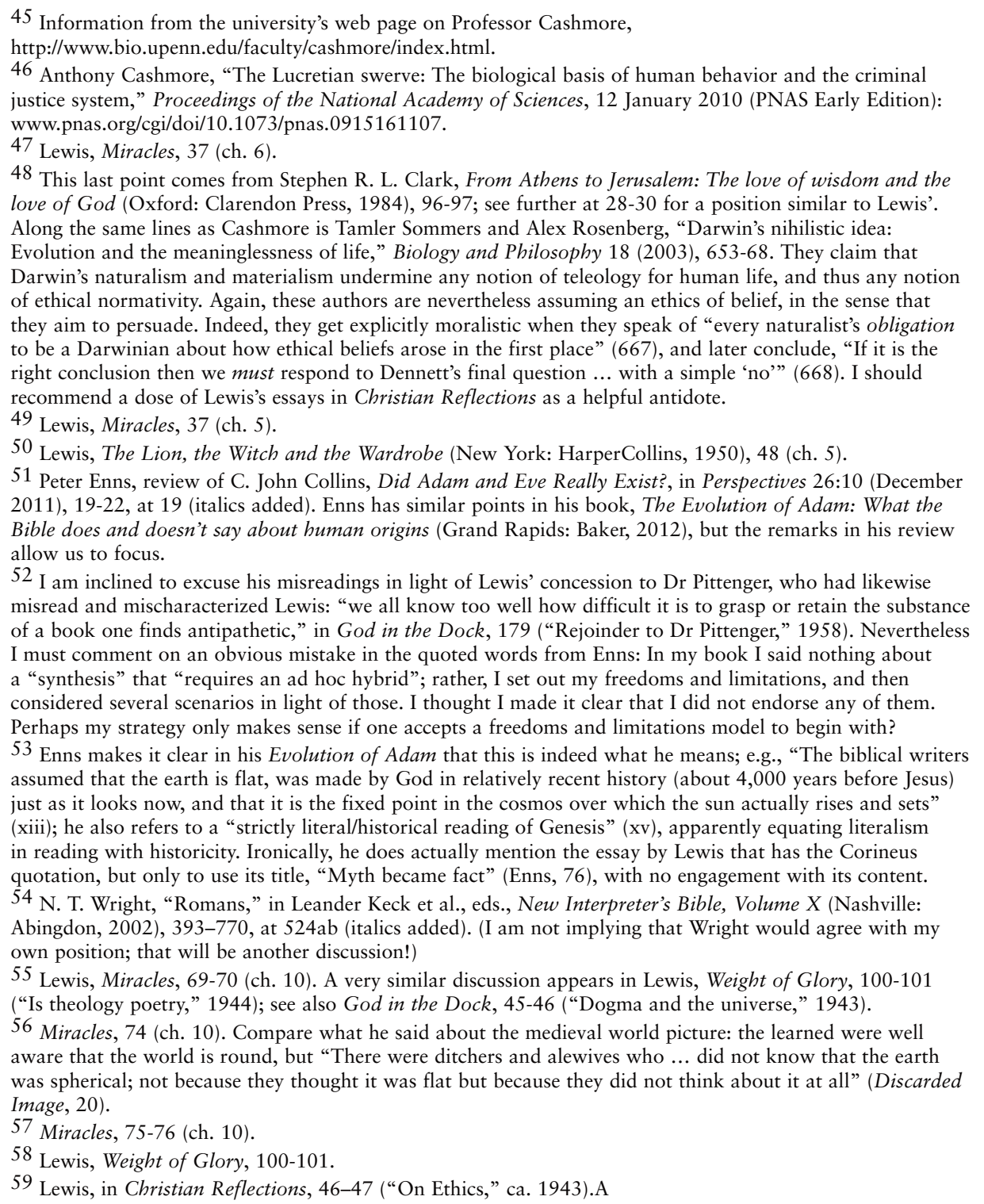

